\title{
Re-Orientation of Legal Policy for Using of Foreign Workers in Indonesian Justice
}

\author{
Andri Winjaya Laksana*) and Jarot Jati Bagus S.**) \\ *) Faculty of Law, Universitas Islam Sultan Agung Semarang, E-mail: \\ andriwinjaya@gmail.com \\ **) Faculty of Law, Universitas Islam Sultan Agung Semarang, E-mail:
} jarotjati21@gmail.com

\begin{abstract}
The existence of foreign workers, which so far has not been balanced with clear legal arrangements, has in its development led to problems of legal certainty in the field of employment. This writing uses doctrinal research or normative juridical research as for the research results obtained that the re-orientation of the implementation of legal policies on the use of foreign workers has not been able to achieve justice. This is because the legal politics of the use of foreign workers has resulted in reduced job opportunities for domestic workers, which in turn resulted in unemployment and poverty problems. Weaknesses in the implementation of the politics of using foreign workers are the shortcomings in the form of time limits and the amount of use of foreign workers is not clearly regulated in the politics of foreign labor law in Indonesia, then the weakness in the case of dualism in work permits for foreigners in Act No. 13 of 2003 and Act No. 6 of 2011.
\end{abstract}

Keyword: Foreign Workers; Legal Policy; Re-orientation.

\section{INTRODUCTION}

The problem of manpower or labor is a typical problem that we hear for developing countries, including Indonesia. One of these problems is the termination of employment by companies, as is the case with unilateral termination of employment by companies in Indonesia. ${ }^{1}$

The low wages and welfare of workers basically occur as a result of the politics of labor law in Indonesia which is still considered to be in favor of the entrepreneurs. Kwik Kian Gie stated that the low wages of workers in Indonesia have always been the main capital to attract foreign investors and seek profit from selling Indonesian products in

\footnotetext{
${ }^{1}$ Nikodemus Maringan, Tinjauan Yuridis Pelaksanaan Pemutusan Hubungan Kerja (PHK) Secara Sepihak Oleh Perusahaan Menurut Undang-Undang No. 13 Tahun 2003 tentang Ketenagakerjaan, Jurnal IImu Hukum Legal Opinion, 3th Editon, Vol 3, 2015, p.1-10
} 
the free market. ${ }^{2}$ Basically, the sad condition of Indonesian workers is due to the emergence of the tyrannical agendas of developed countries through the tempting economic globalization. This fact makes the condition of Indonesian workers facing development problems such as poverty and inequality in income distribution continues to worsen. This fact has led to the emergence of controversial issues in development economics which generally reflect political and economic uncertainty about the political acceptance of theories in basic solutions such as increasing productive unemployment, eliminating rural and urban poverty, and reducing economic and social inequality. ${ }^{3}$ This is getting cloudier with the fact that the Indonesian state in the era of the Asean Economic Community is currently being invaded by foreign workers.

Foreign workers according to Presidential Regulation Number 20 of 2018 concerning Foreign Workers are foreign citizens holding visas who intend to work in Indonesia. This shows that every foreign citizen holding a visa can easily enter to become a Foreign Worker. In its development, the arrival of foreign workers also provides benefits for the country of origin of the foreign worker, one of which is reducing unemployment. ${ }^{4}$

The Ministry of Manpower of the Republic of Indonesia (Kemnaker) noted that throughout 2016 there were 74,183 Foreign Workers in Indonesia. Where foreign workers from China are the largest, with 21,271 people followed by Japan with 12,490 people and the Republic of Korea with 8,424 people. $^{5}$ The increasing number of Foreign Workers in Indonesia is also supported by the Presidential Regulation Number 20 of 2018. This Presidential Regulation gives Chinese investors the freedom to use and bring in large numbers of workers from their country, this can be seen in the provisions of Article 3 letter c Presidential Regulation Number 20 of 2018 which states that the parties that can bring in foreign workers are foreign private companies who are doing business in Indonesia. In addition, the article also provides a gap for foreign workers who do not only come from China to come to Indonesia through work calls from institutions as stated in Article 3 of Presidential Regulation Number 20 of 2018. Meanwhile, Act No. 13 of 2003 has not fully regulated related to foreign workers.

Through this Presidential Regulation, the government focuses on increasing investment in Indonesia by providing easy processes, ease of bureaucracy, especially for foreign workers. But then this Presidential Regulation caused polemics and turmoil in the community, especially from workers in Indonesia. They consider this presidential regulation to legitimize the entry of foreign workers to work in Indonesia. They consider the invasion of foreign workers to threaten the employment opportunities that

\footnotetext{
2 Kwik Kian Gie, Gonjang-Ganjing Ekonomi Indonesia, Badai Beleum Segera Akan Berlalu, Gramedia Pustaka Utama, Jakarta, 1998, p. 565.

${ }^{3}$ Akhmad Nur Zaroni, Globalisasi Ekonomi dan Implikasinya Bagi Negara-Negara Berkembang : Telaah Pendekatan Ekonomi Islam, AL-TIJARY, Vol. 01, No. 01, December 2015, p.1-22

${ }^{4}$ Vina Benita Laksono, Triesanto Romulo Simanjuntak, dan Christian H. J. de Fretes, Dampak Perang Dagang Amerika Serikat-Cina Terhadap Pertumbuhan Investasi Asing Di Vietnam Tahun 2018-2019, Cakrawala: Jurnal Penelitian Sosial, Vol. 9, No. 2, 2020, p. 120-121.

${ }^{5}$ Ahmad Jazuli, The Existence of Foreign Workers in Indonesia From The Immigration Law Perspective, Jurnal IImiah Kebijakan Hukum, Vol. 12 No.1 March 2018, p.89-105
} 
should be obtained by Indonesian workers. Especially with the incessant news about the invasion of Foreign Workers from China. ${ }^{6}$

In addition, between Presidential Regulation Number 20 of 2018 and Act No. 13 of 2003 there is disharmony. This can be seen in the provisions of Article 9 of the Presidential Regulation Number 20 of 2018 which states that the ratification of the Plan for the Use of Foreign Workers (RPTKA) is a requirement for obtaining a work permit. This is different from the provisions of Article 43 of Act No. 13 of 2003 which not only makes RPTKA the only entry for Foreign Workers into the Indonesian State. However, foreign workers must also have a permit in the form of a foreign worker permit. In addition, Article 9 of the Presidential Regulation Number 20 of 2018 also contradicts Article 8 of the Presidential Regulation Number 72 of 2014 concerning Foreign Workers which states that foreign workers can work in Indonesia on condition that they have an RPTKA and a permit to employ foreign workers from entrepreneurs who employ foreign workers. The disharmony of Article 9 of Presidential Decree No. 20 of 2018 with various provisions of labor law in Indonesia shows that the making of Presidential Decree No. 20 of 2018 did not go through a mature academic study. It is clear that the current politics of labor law still has many weaknesses in terms of regulating foreign workers which in the end will be able to cause employment problems and problems of providing employment opportunities for indigenous Indonesians who need livelihoods and the feasibility of economic life in this country. ${ }^{7}$

The entry of foreign workers from China as mentioned above has resulted in a large increase in unemployment in this country. Unemployment conditions in Indonesia are still quite high despite a downward trend in the unemployment rate. The unemployment rate has decreased in line with increasing economic growth. In the case of Indonesia, every $1 \%$ increase in economic growth causes unemployment to fall by 58,617 people. So it can also be concluded that the failure of labor law politics in Indonesia will have an impact on increasing poverty rates in Indonesia due to the increase in unemployment in Indonesia as one of the impacts of the flood of foreign workers in Indonesia with the number of job opportunities dwindling. This is clearly contrary to the Fifth Precepts of Pancasila and Article 27 point 2 of the 1945 Constitution of the Republic of Indonesia regarding the right to have a job and a decent living for Indonesian citizens. ${ }^{8}$

The purpose of this study is to analyze and find out about regulatory issues related to the use of Foreign Workers which so far have not been fully regulated, as one example regarding the limit on the number of uses of Foreign Workers.

\section{RESEARCH METHODS}

\footnotetext{
${ }^{6}$ Lis Setiyowati, Budi Ispriyarso, Asas Keadilan Dalam Peraturan Presiden Nomor 20 Tahun 2018 Tentang Penggunaan Tenaga Kerja Asing, Refleksi Hukum, Vol 3 No 1, October 2018, p.67-80

${ }^{7}$ Riza Fauziah Djazuli, Dinamika Pengaturan Tenaga Kerja Asing Di Indonesia, ADLIYA: Jurnal Hukum dan Kemanusiaan, Vol. 15, No. 1 2018, p. 14-15.

${ }^{8}$ Fithriatus, Shalihah, Perjanjian Kerja Waktu Tertentu (PKWT) Dalam Hubungan Kerja Menurut Hukum Ketenagakerjaan Indonesia Dalam Perspektif HAM, Jurnal UIR Law Review, 1 (2), 2017, p. $149-151$.
} 
This research is a qualitative research, it is hoped that it can produce a descriptive about the values of justice for the benefit of society in general related to the current political ability of labor law in facing the challenges of globalization, so this writing uses a normative juridical approach. ${ }^{9}$ The type of data used is qualitative data which consists of primary and secondary data, as we know that both primary and secondary data complement each other. In order to obtain answers to the problems being researched by taking an inventory of data relating to the implementation of the current political capabilities of labor law in facing the challenges of globalization in several regions in Indonesia. ${ }^{10}$ While the secondary data in this study is legislation related to the current political capacity of labor law in facing the challenges of globalization. ${ }^{11}$ The data analysis in this paper uses descriptive qualitative analysis by comparing secondary data and primary data, looking for weaknesses in the current political capabilities of labor law in facing the challenges of globalization, and determining new ideas related to the political capabilities of labor law in facing the challenges of fair globalization.

\section{RESULT AND DISCUSSION}

\subsection{Implementation of Legal Policies Related to Regulating the Use of Foreign Workers in Indonesia Currently}

In its development, the implementation of foreign labor law politics in Indonesia has problems, namely the issue of limits on the number of foreign workers, time limits for the use of foreign workers, and supervision of the use of foreign workers. ${ }^{12}$ Regarding the issue of the period of use of foreign workers, it is clearly regulated in the Decree of the Minister of Manpower and Transmigration No. 228 of 2003 concerning RPTKA which states that the time limit for the use of foreign workers is only five years but can be extended by considering the needs of foreign workers and market conditions domestic work. ${ }^{13}$

This is different from the provisions in Article 9 paragraph (2) of Ministerial Regulation Number 10 of 2018 concerning Procedures for the Use of Foreign Workers which states that "the period of RPTKA as referred to in paragraph (1) is in accordance with the work agreement or work agreement". This clearly shows that the implementation of

\footnotetext{
'Laurensius Arliman S, Peranan Metodologi Penelitian Hukum di dalam Perkembangan Ilmu Hukum di Indonesia, Soumatera Law Review, Vol. 1, No. 1, 2018, p. 112.

${ }^{10}$ F.C. Susila Adiyanta, Hukum dan Studi Penelitian Empiris: Penggunaan Metode Survey sebagai Instrumen Penelitian Hukum Empiris, Adminitrative Law \& Governance Journal, Vol. 2, No. 4, 2019 , p.697.

${ }^{11}$ Kornelius Benuf dan Muhamad Azhar, Metodologi Penelitian Hukum sebagai Instrumen Mengurai Permasalahan Hukum Kontemporer, Jurnal Gema Keadilan, Volume 7 Edisi I, June 2020, p. 21-22.

${ }^{12}$ Firda Zahrani Hidayat, Palupi Lindiasari Samputra, dan Heru Subiyantoro, Analisis Pengaruh Substitusi Tenaga Kerja Asing Terhadap Tenaga Kerja Domestik Pada Masa Sebelum dan Sesudah Kebijakan Bebas Visa Kunjungan Di Indonesia, Jurnal Ekonomi Kuantitatif Terapan, vol. 13, No. 2, 2020, p. 284-286.

${ }^{13}$ Nurhidayati, Perizinan Tenaga Kerja Asing Kebijakan dan Implementasinya, Widya Cipta: Jurnal Sekretari dan Manajemen, 3 (2), 2019, p. 243-245.
} 
the policy on the use of foreign workers so far does not contain strict and clear limits on the length of use of foreign workers. ${ }^{14}$

Although they have differences in terms of language substance, however, both the Decree of the Minister of Manpower and Transmigration Number 228 of 2003 concerning RPTKA and Ministerial Regulation Number 10 of 2018 concerning Procedures for the Use of Foreign Workers, have the same meaning, namely the time limit for the use of Foreign Workers based on the decision of users of Foreign Workers or entrepreneurs who employ Foreign Workers.

Then related to the limit on the number of foreign workers who can be accepted to work in Indonesia, it is not regulated in the legal politics of foreign workers. This has resulted in the growth rate of the number of Foreign Workers in the job market in Indonesia being out of control.

The increasing number of foreign workers arriving in Indonesia is a dilemmatic phenomenon, on the one hand the entry of foreign workers is believed to increase domestic investment. However, the entry of foreign workers will also raise new problems with the narrowness of the work area for Indonesian workers because they have to compete with foreign workers. Furthermore, Nurhidayati, another problem with foreign workers is the large number of unskilled foreign workers or unskilled laborers (unskilled labour), especially from China. The rise of unskilled foreign workers to Indonesia, of course, if viewed from the labor regulations that require foreign workers to have education and potential certification, this is a violation. However, the government itself indirectly does not mind this. ${ }^{15}$

Implementation of legal policies applied to foreign workers as a filter in realizing legal protection for Indonesian workers who compete with foreign workers. Budiono said that Workers protection is intended to guarantee the basic rights of workers and ensure equality of opportunity and treatment without discrimination on any basis whatsoever for the welfare of workers and their families with regard to the progress of the business world. ${ }^{16}$ So that by providing legal protection for Indonesian workers, Haingo Rabarijaona added: In its development, in order to improve performance and also improve the quality of workers, it is necessary to ensure a definite life and deserve to be obtained by someone who can also result in an increase in the quality of the existing workforce by increasing the protection of workers who must be in accordance with dignity and human rights itself. ${ }^{17}$

In its implementation regarding the application of legal policies, it can be explained that Act No. 13 of 2003 does not implicitly regulate foreign workers clearly, as a result,

\footnotetext{
${ }^{14}$ Rahmat, Ramadhani dan Ramlan., Perjanjian Build Operate And Transfer (Bot) Lapangan Merdeka Medan Dalam Pandangan Hukum Adminsitrasi Negara Dan Hukum Bisnis, De Lega Lata: Jurnal IImu Hukum, 4 (2), 2019, p. 254-257.

${ }^{15}$ Nurhidayati, Op.Cit, p.241-248

16 Budiyono, Reconstruction of Indonesian Labour Regulation to The Interests Workers In Indonesia (Reviewing About Salary), Jurnal Pembaharuan Hukum, Vol V No.2 April-August 2018, p.244-252.

17 Haingo Rabarijaona, Devina Arifani, Legal Protection of Employees / Workers Who Experienced Employment Relationship Impact Digitalization, Jurnal Pembaharuan Hukum, Volume 7, Number 3, December 2020, p.211-221
} 
a number of these regulations are still delegated with implementing regulations. Therefore, the regulation of foreign workers becomes very flexible, which makes it easy to change the rules. One of them is the regulations contained in the 2015 Minister of Manpower Regulation, this regulation has been amended 2 times, namely the Minister of Manpower Regulation Number 16 of 2015 has been amended by the Minister of Manpower Regulation Number 35 of 2015. One of them is the abolition of obligations for employers employment to absorb at least 10 Indonesian workers if employing 1 Foreign Worker and there is no longer any provision for foreign nationals to be able to speak Indonesian. This means that Indonesian is not a must. Thus, it will have negative and positive impacts, such as the large number of foreign workers who flock to Indonesia not to learn to speak Indonesian, not to hinder the entry of foreign capital, while the negative impact is to hinder the transfer of technology from foreign workers to accompanying Indonesian workers. Other requirements that are often violated in practice, such as positions or forms of work that can be carried out by foreign workers. ${ }^{18}$

Based on this, Agusmidah said that the application of legal policies that regulate foreign workers must also pay attention to the requirements that must be met by foreign workers in Indonesia, including having a competency certificate or work experience certificate in accordance with the position occupied by foreign workers at least 5 (five) years, make a statement letter of obligation to transfer their expertise to the accompanying TKI as evidenced by a report on the implementation of education and training. Permit to use foreign workers is the next step after the employer has obtained a plan to use foreign workers (RPTKA). ${ }^{19}$

Permit to employ foreign workers is the next step after the employer has approved the plan to use foreign workers (RPTKA). The permit for the use of foreign workers is the next step after the employer gets the approval of the Plan for the Use of Foreign Workers (RPTKA). Regarding the permit, it is regulated in the Regulation of the Minister of Manpower Number 35 of 2015 concerning Amendments to the Regulation of the Minister of Manpower Number 16 of 2015 concerning Procedures for the Use of Foreign Workers.

The conditions that must be met by foreign workers are first, have an education that is in accordance with the requirements of the position to be occupied by foreign workers; second, have a certificate of competence or have work experience in accordance with the position to be occupied by Foreign Workers for at least 5 (five) years; third, a statement letter must transfer their expertise to the accompanying Indonesian Migrant Workers as evidenced by a report on the implementation of education and training; fourth, having NPWP for Foreign Workers who have worked for more than 6 (six) months; fifth, have proof of insurance policy on insurance that is an Indonesian legal

18 Risky Vista Puspita Sari, Aries Harianto, Ida Bagus Oka Ana, Kepastian Hukum Pengaturan Penggunaan Tenaga Kerja Asing di Indonesia, Lentera Hukum, Volume 5 Issue 3 (2018), p.389402

${ }^{19}$ Agushamidah, Dinamika \& Kajian Teori Hukum Ketenagakerjaan Indonesia, Ghalia Indonesia, Jakarta, 2010, p. 113. 
entity; sixth, National Social Security participation for Foreign Workers who work more than 6 (six) months. ${ }^{20}$

In connection with the granting of permits, Nina Juwitasari conveyed that the agency authorized to supervise companies and workers who employ foreign workers is the Ministry of Manpower as the agency that provides permits for the placement of foreign workers. While the supervision of workers as foreigners is the authority of the Directorate General of Immigration in charge of supervising when they enter, as well as the activities carried out while in Indonesian territory. To employ skilled workers, supervision is in the technical department according to their expertise, such as Foreign Legal Consultants, in the Ministry of Law and Human Rights. Furthermore, in terms of implementing law enforcement in the context of supervising the use of Foreign Workers, it is carried out through coordination, both at the central and regional levels with relevant agencies in accordance with the authority of each agency. ${ }^{21}$

\subsection{Weaknesses in the Implementation of Legal Policies Related to Regulating the Use of Foreign Workers in Indonesia Currently}

Technological developments in all areas of life, including in the fields of transportation, information, and the economy, have resulted in increasingly thinning national boundaries and the activities of people entering and leaving the territory of Indonesia will be bigger and more difficult to contain. ${ }^{22}$ Currently, the discourse of labor market liberalization is starting to be discussed in Southeast Asia, which is apparently difficult to make uniformity in making regulations regarding the labor market. This is because each country makes its own regulations, and there is no standardization of work skills in the Southeast Asian region. In Indonesia itself, the government has responded to the liberalization of the labor market by revising various labor laws and regulations which regulate foreign workers. ${ }^{23}$

The implementation of laws and regulations regarding the control and supervision of Foreign Workers is not yet optimal. Especially in terms of coordination that should be carried out by relevant agencies so that it has an impact on increasing immigration violations committed by foreign workers. ${ }^{24}$ In order to deal with the effects of globalization which has led to more and more foreign workers entering Indonesia, it must be anticipated that the implementation of labor law regulations is actually implemented in the use of foreign workers.

A similar study on foreign workers related to the draft job creation law has been carried out which results in the conclusion that the ratification of the job creation law

\footnotetext{
${ }^{20}$ Ibid.

${ }^{21}$ Nina Juwitasari, Sonhaji, Solechan, Implikasi Yuridis Keberadaan Tenaga Kerja Asing Sebagai Tenaga Kerja di Indonesia, Diponegoro Law Review, Vol 5, No 2, 2016, p.1-8

22 Jazim Hamidi dan Charles Christian, Hukum Keimigrasian Bagi Orang Asing Di Indonesia, Sinar Grafika Jakarta, 2015, p.10

${ }^{23}$ Agusmidah, Dilematika Hukum Ketenagakerjaan Tinjauan Politik Hukum, Sofmedia, Medan, 2011 , p. 350.

${ }^{24}$ Suhandi, Pengaturan Ketenagakerjaan Terhadap Tenaga Kerja Asing Dalam Pelaksanaan Masyarakat Ekonomi Asean di Indonesia, Perspektif, Vol.XXI No.2 Edition March 2016, p.135148
} 
has an impact on cutting entry permits for foreign workers. ${ }^{25}$ Until now, foreign workers only require the use of foreign workers (RPTKA). Then in Article 46 of Act No. 13 of 2003, foreign workers are prohibited from occupying positions in charge of personnel and certain positions whose details are regulated by a Ministerial Decree. In the rules contained in the Employment Creation Act, an article regarding the limitation of positions for foreign workers in Indonesian companies is abolished, namely Article 46 of Act No. 13 of 2003 concerning Manpower.

In addition, Article 42 of the Employment Creation Law, the Manpower Chapter, describes foreign workers. Article 42 paragraph 1 states that every employer who employs foreign workers is required to have a plan for the use of foreign workers approved by the Central Government. While individual employers are prohibited from employing foreign workers, this is regulated in Article 42 paragraph (2) of the Job Creation Law. Plan for Employment of Foreign Workers, hereinafter referred to as RPTKA, is a plan for the use of foreign workers which is an initial document that must be prepared by employers of foreign workers in certain positions made by the employer of foreign workers for a certain period of time which is legalized by the minister or appointed official. RPTKA is useful as a basis for obtaining a permit to employ foreign workers. ${ }^{26}$

Based on a study of the orientation towards the rise of foreign workers entering Indonesia, we can draw conclusions regarding weaknesses in the implementation of legal policies related to regulating the use of foreign workers in Indonesia, among others:

\subsection{Weaknesses in the Implementation of Foreign Employment Law Politics}

According to Mahfud MD, legal politics is a legal policy that will be or has been implemented nationally by the Government of Indonesia which includes: First, the development of laws with the core of making and updating legal materials so that they can be in accordance with needs; second, the implementation of existing legal provisions, including the affirmation of the function of the institution and the guidance of law enforcers. From this understanding, it can be seen that legal politics includes the process of making and implementing laws that can indicate the nature and direction in which the law will be built and enforced. ${ }^{27}$

It has been explained above that the implementation of foreign labor law politics in Indonesia has problems, namely the issue of limits on the number of Foreign Workers, time limits for the use of Foreign Workers, and supervision of the use of Foreign Workers. Regarding the issue of the period of use of foreign workers, it has been clearly regulated in the Decree of the Minister of Manpower and Transmigration Number 228 of 2003 concerning RPTKA which states that the time limit for the use of

\footnotetext{
${ }^{25}$ Ida Hanifah, Peluang Tenaga Kerja Asing Untuk Bekerja di Indonesia Berdasarkan Rancangan Undang-Undang Cipta Kerja, Delegalata Jurnal Ilmu Hukum, Vol.6 No. 1 (2021). P.158-173

26 Adella Virginia Z, Rencana Penggunaan Tenaga Kerja Asing (RPTKA) Sebagai Izin Menggunakan Tenaga Kerja Asing di Indonesia, Jurist-Diction, Vol. 2 No. 2, March 2019, p.347360

27 Mahfud MD, Politik Hukum Di Indonesia, Rajawali Pers, Jakarta, 2010, p.17
} 
foreign workers is only five years but can be extended by considering the needs of foreign workers and circumstances domestic job market.

The problem that arises is that the number of foreign workers working in Indonesia is increasing, the legal impact of the problem is in the form of increasing violations of various laws and regulations regarding immigration, where many foreigners are negligent or intentionally do not report in carrying out their obligations as intended. in article 71 letter a of Act No. 6 of 2011 concerning immigration, namely the obligation of foreigners to provide all information regarding the identity of themselves and their families and to report any change in civil status, citizenship, employment, guarantor, or change of address to the local immigration office. Another economic impact, the presence of foreign workers may close job opportunities for Indonesian citizens in obtaining strategic positions in a particular company. ${ }^{28}$

Then related to the limit on the number of foreign workers who can be accepted to work in Indonesia, it is not regulated in the legal politics of foreign workers. This has resulted in the growth rate of the number of foreign workers in the job market in Indonesia being out of control.

\subsection{Weaknesses in Protecting the Position of Indonesian Workers in Competition with Foreign Workers in the Domestic Job Market}

Basically, the spirit of the existence of foreign workers in Indonesia is for the advancement of development technology, the advancement of the development performance system, and the improvement of domestic human resources. However, the legal politics of foreign workers has far ruled out the position of Indonesian workers.

This is because legal politics related to national development has neglected aspects of human resource development by neglecting education financing, resulting in a lack of access to adequate education for the wider community in Indonesia. In the development of labor law politics in Indonesia, this issue has also been put aside by further emphasizing the open space for free competition in the domestic labor market which is affected by the globalization system of the world economy. This will obviously result in the elimination of Indonesian workers from the competition in the domestic job market.

The weaknesses above are due to factors such as:

\section{a. Legal Regulatory Factor}

The issue of the period of use of foreign workers has been clearly regulated in the Decree of the Minister of Manpower and Transmigration Number 228 of 2003 concerning RPTKA which states that the time limit for the use of foreign workers is only for five years but can be extended by considering the needs of foreign workers and market conditions domestic work. This is different from the provisions in Article 9 paragraph (2) of Ministerial Regulation Number 10 of 2018 concerning Procedures for the Use of Foreign Workers which states that "the period of RPTKA as referred to in paragraph (1) is in accordance with the work agreement or work agreement". This clearly shows that the implementation of the policy on the use of foreign workers so far does not contain strict and clear limits on the length of time for the use of foreign workers.

28 Anis Tiana Pottag, Politik Hukum Pengendalian Tenaga Kerja Asing Yang Bekerja Di Indonesia, Media Iuris, Vol. 1 No. 2, June 2018, p.236-250 
Although they have differences in terms of language substance, however, both the Decree of the Minister of Manpower and Transmigration Number 228 of 2003 concerning RPTKA and Ministerial Regulation Number 10 of 2018 concerning Procedures for the Use of Foreign Workers, have the same meaning, namely the time limit for the use of Foreign Workers based on at the decision of foreign workers or entrepreneurs who employ foreign workers. This is clearly contrary to Article 42 Paragraph (6) of Act No. 13 of 2003 which states that "foreign workers as referred to in paragraph (4) whose working period has expired and cannot be extended can be replaced by other foreign workers".

Then related to the limit on the number of foreign workers who can be accepted to work in Indonesia, it is not regulated in the legal politics of foreign workers. This has resulted in the growth rate of the number of Foreign Workers in the job market in Indonesia being out of control. Legal regulations that are embodied in legal principles are general and abstract basic thoughts. However, legal principles exist in every legal system and are incarnated in every positive law so that they can be found by tracing the general characteristics of legal regulations. ${ }^{29}$

b. Law Enforcement Factor

Regarding the issue of regulation of Foreign Workers, it is clear that the Ministry of Manpower and Transmigration and its institutions at the regional level act in accordance with the mouthpiece of the law. Besides that, the opportunities for corruption, collusion and nepotism are very large considering that the world of manpower is very closely related to parties with capital which often overrides the rights of domestic workers.

\section{c. Legal Culture Factors}

The actual legal culture factors Unified with the community factors are deliberately distinguished, because in the discussion the problem of the value system that is the core of spiritual or non-material culture will be raised. The culture of the legal system basically includes values, which are abstract conceptions of what is considered good to be followed and what is considered bad to be avoided. These values are usually a pair of values that reflect two extreme conditions that must be harmonized. This will be the subject of discussion in this section on cultural factors. ${ }^{30}$

National legal politics in Indonesia in its development was unable to free itself from the grip of economic globalization that was present through the liberalization of national legal policies which resulted in national legal politics having been far at odds with the mandate of Pancasila and the fourth paragraph of the Preamble to the 1945 Constitution of the Republic of Indonesia. This also occurred in the realm of legal politics of settlement the issue of industrial expatriate workers. Economic globalization has resulted in the birth of a borderless state, invisible hand, and of course the dept trap. The various problems brought by economic globalization have resulted in various kinds of intrusion of the interests of the tyrannical state against the Indonesian state, especially in the field of Manpower.

\footnotetext{
29 Dewi Astutty Mochtar, Pengantar IImu Hukum, Bayumedia Publishing, Malang, 2012, p. 77

${ }^{30}$ Asrilia Bayi Saka Putri, Gunarto, Perlindungan Hukum Karyawan Notaris Pada Perjanjian Kerja Waktu Tertentu (PKWT), Jurnal Akta, Vol. 4 No. 4 December 2017, p.535-544
} 


\section{CONCLUSION}

The re-orientation of the implementation of legal policies on the use of foreign workers has not been able to achieve justice. This is because the legal politics of the use of foreign workers has resulted in reduced job opportunities for domestic workers, which in turn resulted in unemployment and poverty problems. Weaknesses in the implementation of the politics of using foreign workers are the shortcomings in the form of time limits and the amount of use of foreign workers is not clearly regulated in the politics of foreign labor law in Indonesia, then the weakness in the case of dualism in work permits for foreigners in Act No. 13 of 2003 and Act No. 6 of 2011.

\section{REFERENCES}

Journals:

Adella Virginia Z, Rencana Penggunaan Tenaga Kerja Asing (RPTKA) Sebagai Izin Menggunakan Tenaga Kerja Asing di Indonesia, Jurist-Diction, Vol. 2 No. 2, March 2019;

Ahmad Jazuli, The Existence of Foreign Workers in Indonesia from The Immigration Law Perspective, Jurnal IImiah Kebijakan Hukum, Vol. 12 No.1 March 2018;

Akhmad Nur Zaroni, Globalisasi Ekonomi dan Implikasinya Bagi Negara-Negara Berkembang : Telaah Pendekatan Ekonomi Islam, AL-TIJARY, Vol. 01, No. 01, December 2015;

Anis Tiana Pottag, Politik Hukum Pengendalian Tenaga Kerja Asing Yang Bekerja Di Indonesia, Media Iuris, Vol. 1 No. 2, June 2018;

Asrilia Bayi Saka Putri, Gunarto, Perlindungan Hukum Karyawan Notaris Pada Perjanjian Kerja Waktu Tertentu (PKWT), Jurnal Akta, Vol. 4 No. 4 December 2017;

Budiyono, Reconstruction of Indonesian Labour Regulation to The Interests Workers In Indonesia (Reviewing About Salary), Jurnal Pembaharuan Hukum, Vol V No.2 April-Agustus 2018;

F.C. Susila Adiyanta, Hukum dan Studi Penelitian Empiris: Penggunaan Metode Survey sebagai Instrumen Penelitian Hukum Empiris, Adminitrative Law \& Governance Journal, Vol. 2, No. 4, 2019;

Firda Zahrani Hidayat, Palupi Lindiasari Samputra, dan Heru Subiyantoro, Analisis Pengaruh Substitusi Tenaga Kerja Asing Terhadap Tenaga Kerja Domestik Pada Masa Sebelum dan Sesudah Kebijakan Bebas Visa Kunjungan Di Indonesia, Jurnal Ekonomi Kuantitatif Terapan, vol. 13, No. 2, 2020;

Fithriatus, Shalihah, Perjanjian Kerja Waktu Tertentu (PKWT) Dalam Hubungan Kerja Menurut Hukum Ketenagakerjaan Indonesia Dalam Perspektif HAM, Jurnal UIR Law Review, 1 (2), 2017;

Haingo Rabarijaona, Devina Arifani, Legal Protection of Employees / Workers Who Experienced Employment Relationship Impact Digitalization, Jurnal Pembaharuan Hukum, Volume 7, Number 3, December 2020;

Ida Hanifah, Peluang Tenaga Kerja Asing Untuk Bekerja di Indonesia Berdasarkan Rancangan Undang-Undang Cipta Kerja, Delegalata Jurnal IImu Hukum, Vol.6 No. 1 (2021);

Kornelius Benuf dan Muhamad Azhar, Metodologi Penelitian Hukum sebagai Instrumen Mengurai Permasalahan Hukum Kontemporer, Jurnal Gema Keadilan, Volume 7 Edisi I, June 2020;

Laurensius Arliman S, Peranan Metodologi Penelitian Hukum di dalam Perkembangan 
Ilmu Hukum di Indonesia, Soumatera Law Review, Vol. 1, No. 1, 2018;

Lis Setiyowati, Budi Ispriyarso, Asas Keadilan Dalam Peraturan Presiden Nomor 20 Tahun 2018 Tentang Penggunaan Tenaga Kerja Asing, Refleksi Hukum, Vol 3 No 1, October 2018;

Nikodemus Maringan, Tinjauan Yuridis Pelaksanaan Pemutusan Hubungan Kerja (PHK) Secara Sepihak Oleh Perusahaan Menurut Undang-Undang No. 13 Tahun 2003 tentang Ketenagakerjaan, Jurnal IImu Hukum Legal Opinion, 3th Editon, Vol 3, 2015;

Nina Juwitasari, Sonhaji, Solechan, Implikasi Yuridis Keberadaan Tenaga Kerja Asing Sebagai Tenaga Kerja di Indonesia, Diponegoro Law Review, Vol 5, No 2, Tahun 2016;

Nurhidayati, Perizinan Tenaga Kerja Asing Kebijakan dan Implementasinya, Widya Cipta: Jurnal Sekretari dan Manajemen, 3 (2), 2019;

Rahmat, Ramadhani dan Ramlan., Perjanjian Build Operate And Transfer (Bot) Lapangan Merdeka Medan Dalam Pandangan Hukum Adminsitrasi Negara Dan Hukum Bisnis, De Lega Lata: Jurnal IImu Hukum, 4 (2), 2019;

Riza Fauziah Djazuli, Dinamika Pengaturan Tenaga Kerja Asing Di Indonesia, ADLIYA: Jurnal Hukum dan Kemanusiaan, Vol. 15, No. 1 2018;

Risky Vista Puspita Sari, Aries Harianto, Ida Bagus Oka Ana, Kepastian Hukum Pengaturan Penggunaan Tenaga Kerja Asing di Indonesia, Lentera Hukum, Volume 5 Issue 3 (2018);

Suhandi, Pengaturan Ketenagakerjaan Terhadap Tenaga Kerja Asing Dalam Pelaksanaan Masyarakat Ekonomi Asean di Indonesia, Perspektif, Vol.XXI No.2 Edition March 2016;

Vina Benita Laksono, Triesanto Romulo Simanjuntak, dan Christian H. J. de Fretes, Dampak Perang Dagang Amerika Serikat-Cina Terhadap Pertumbuhan Investasi Asing Di Vietnam Tahun 2018-2019, Cakrawala: Jurnal Penelitian Sosial, Vol. 9, No. 2, 2020;

Books:

Agushamidah, 2010, Dinamika \& Kajian Teori Hukum Ketenagakerjaan Indonesia, Ghalia Indonesia, Jakarta;

Agusmidah, 2011, Dilematika Hukum Ketenagakerjaan Tinjauan Politik Hukum, Sofmedia, Medan;

Dewi Astutty Mochtar, 2012, Pengantar Ilmu Hukum, Bayumedia Publishing, Malang;

Jazim Hamidi dan Charles Christian, 2015, Hukum Keimigrasian Bagi Orang Asing Di Indonesia, Sinar Grafika Jakarta;

Kwik Kian Gie, 1998, Gonjang-Ganjing Ekonomi Indonesia, Badai Beleum Segera Akan Berlalu, Gramedia Pustaka Utama, Jakarta;

Mahfud MD, 2010, Politik Hukum Di Indonesia, Rajawali Pers, Jakarta;

Regulations:

Act No. 13 of 2003 concerning Manpower

Regulation of the Minister of Manpower Number 16 of 2015 Procedures for the Use of Foreign Workers

Regulation of the Minister of Manpower of the Republic of Indonesia Number 10 of 2018 Procedures for the Use of Foreign Workers

Decree of the Minister of Manpower and Transmigration Number 228 of 2003 concerning the Plan to Use Foreign Workers 